ReVISTA de BIOLOGía TROPICAL

\title{
Seed deposition in the edge-interior gradient of a degraded fragment of tropical semideciduous forest, Northeastern Brazil
}

\author{
Ivan J. S. Diogo ${ }^{1}$, Márcia E. M. Fortunato ${ }^{2}$ \& Itayguara R. Costa ${ }^{3}$ \\ 1. Graduate Program in Plant Biology. State University of Campinas - UNICAMP, Institute of Biology, Department of \\ Plant Biology, 13083-970. Campinas, SP, Brazil; ivan_kdf@yahoo.com.br \\ 2. Graduate Program in Plant Biology. Federal University of Pernambuco - UFPE, Department of Botany, 50670-901, \\ Recife, PE, Brazil; marciaemanuelle@hotmail.com \\ 3. Department of Biology, Federal University of Ceará-UFC, 60440-900 Fortaleza, CE, Brazil; itayguara@gmail.com
}

Received 20-XI-2014. C Corrected 24-VI-2015. Accepted 27-VII-2015.

\begin{abstract}
The structure, dynamics and density of plant populations in different ecosystems are controlled by climatic seasonality. Seed rain contributes to both establishment and maintenance of the forest as well as to the recovery of disturbed areas near forest fragments. The aim of this study was to assess the deposition rate of different seeds of endemic and exotic tree species for the edge and for the interior of the forest matrix. The study area is a four hectares forest fragment located on the campus of the Federal University of Ceará. To measure seed rain, 80 collectors were suspended $20 \mathrm{~cm}$ above the ground in the gradient. Samples were collected monthly for 12 months (June 2009-May 2010), the material was screened in the laboratory and the diaspores (fruits and seeds) were quantified and taxonomically identified. We found 23383 seeds belonging to 38 families and 89 different species, with a density of 134.48 seeds per $\mathrm{m}^{2}$. The families Rubiaceae and Fabaceae were the most representative ones, with more quantities of seeds. The deposition of the seed rain was influenced by season and, consequently, by temperature and rainfall. There was a clear difference between the edge and the forest interior; with a large supply of native, animal dispersed and late successional seeds on the inside, and a considerable number of seeds belonging to non-native species and abiotic dispersion on the edge. Small fragments like this one can serve as important sources of seed for adjacent degraded areas, which demonstrate the importance of conservation and management of small fragments to avoid the degradation caused by edge effects. Rev. Biol. Trop. 63 (4): 981-994. Epub 2015 December 01.
\end{abstract}

Key words: seasonality, alien species, dispersal, succession, life form.

Forest edges are very important for the structure of the landscape (Leopold, 1933; Harris, 1988; Murcia, 1995) and many authors suggest that edges can be a functional (species' diversity) and spatial (patches and matrix areas) component of the ecosystem (Gosz, 1991; Forman, 1995; Pickett \& Cadenasso, 1995). The edges are the main area of contact between forests and other native and anthropic communities, such as areas of constructions, farming and cattle, allowing fluxes of material, energy and organisms from the surrounding area to the forest (Wiens, 1992; Forman, 1995).
The strength and direction of abiotic and biotic fluxes are affected by the edges and can influence directly the dynamic and structure of the forest interior (Wiens, Stenseth, Van Horn, \& Ims, 1993; Pickett \& Cadenasso, 1995). Edges of forest remnants embedded in urban areas suffer constant human action that generate changes in microclimate and soil, which lead to shifts in biological communities and affect ecological processes (Murcia, 1995; Fox, Taylor, Fox, \& Williams, 1997; Fahrig, 2003; Ramos, Buitrago, Pulido, \& Vanegas, 2013). Other important aspects include the 
permeability of the edge (that depend on a species' flux and access to the matrix), the quality of the matrix with respect to survival and facility of movements, and the distance to neighboring patches (Forman \& Moore, 1992; Cadenasso \& Pickett, 2001).

A critical type of flux that forests are increasingly exposed to is species invasion by seed supply (Vitousek, D’Antonio, Loope, Rejmánek, \& Westbrooks, 1997; Pakeman \& Small, 2005). Changes in forest species composition overtime are driven by several factors, including recruitment from the seed and seedling banks, inputs from the seed rain, interactions with standing vegetation and emission of shoots or roots from damaged individuals (Lovett, Canham, Arthur, Weathers, \& Fitzhugh, 2006; Burton, Mladenoff, Clayton, \& Forrester, 2011).

The characteristics and dispersion of the seeds can determine where and how germination and establishment may occur (Swaine \& Whitmore, 1988). Thus, how the seeds are dispersed is essential for natural regeneration and a key for the study of vegetation dynamics (Harper, 1977).

Seed rain is used as an important indicator to understand the regenerative capacity of a forest, depending on the degree of environmental disturbance (Hopkins \& Graham, 1983; Young et al., 1987; Baider et al., 1999), the landscape matrix (Guariguata \& Ostertag, 2001), the dynamics and variation of rain deposition over time under natural conditions (Du, Guo, Gao, \& Ma, 2007) and the dispersal mode (Rodríguez-Pérez, Wiegand, \& Ward, 2011).

Relationships between dispersal efficiency of tropical forest species with the spatial arrangement of the fragments in the landscape and edge effects are poorly addressed in the literature (Cadenasso \& Picket, 2001; Pakeman \& Small, 2005; Pivello et al., 2006; Du, Guo, Gao, \& Ma, 2007). The evaluation of these processes provides important information to understand the dynamics of natural regeneration and species invasion of a forest area.

Our general hypothesis is that the maintenance of the forest is determined by the permeability of the edge in terms of entrance of seeds. To test this hypothesis we focused on dispersal mode and on the spatial distribution of seeds in a fragment of semideciduous tropical forest. We used the edge of a semideciduous forest adjacent to the city center as our study site because this is a common edge type in Northeastern Brazil and provides a clear contrast between forest and non-forest habitats.

We aimed to assess the deposition rate and the functional type of different seeds of endemic and exotic tree species for the edge and for the interior of the forest matrix. We hypothesized that (1) the interior has a greater diversity than the edge, (2) the major depositions of seeds occur after the end of the rainy season, and (3) the forest edge functions as a filter to the flux of abiotic-dispersed, early successional and herbaceous seeds from the surrounding landscape into the forest interior.

\section{MATERIAL AND METHODS}

Study site: The study was conducted in a fragment of semideciduous forest of approximately four ha in the city of Fortaleza, Ceará, Northeastern Brazil, between the geographical coordinates (334'16"79" - 3034'43"49" S) and (38'34'03"81" - 38'34'42"71" W). This forest is located in the city, near to buildings, streets, and avenues and surrounded by a water reservoir (Santo Anastácio). The nearest large forest is located in Parque Botânico do Ceará, has $190000 \mathrm{ha}$ and is distant $15 \mathrm{~km}$ from the study area.

The local climate is Aw, hot and semi humid, according to Köppen-Geiger classification (Peel, Finlayson, \& Mcmahon, 2007). The mean annual temperature is 26 ${ }^{\circ} \mathrm{C}$, ranging from $25{ }^{\circ} \mathrm{C}$ in the coldest months (March and June) to $30{ }^{\circ} \mathrm{C}$ during the hottest months (September to November). The average rainfall varies from $1200 \mathrm{~mm}$ to $1700 \mathrm{~mm}$, depending on the year, and is scattered over two to five months (January to May), which usually contributes to $>80 \%$ of the total annual rainfall. The National Meteorology Institute (INMET) provided climatic data. 
Data collection: Samples were collected monthly for 12 months (June/2009-May/2010), closing the annual cycle of monitoring the seed deposition. The range of the edge effect of a forest is variable depending on vegetation type, development stage of the forest and forest type, here, we considered the edge to be $20 \mathrm{~m}$ from the physical limit between the fragment and the matrix based on a previous study at the area and specialized literature (Diogo, Silva, Morais, Melo, \& Voltolini, 2012; Harper et al., 2005).

To evaluate species composition of the seed rain in this area, we established ten transects perpendicular to the matrix forest, separated from each other by $20 \mathrm{~m}$. Along the edge transects, we placed seed traps at 5, 10, 15 and $20 \mathrm{~m}$ from the matrix forest, while interior transects had seed traps at $30 \mathrm{~m}$ intervals from the edge forest $(30,60,90$ and $120 \mathrm{~m})$, yielding eight traps per transect and 80 overall. Each trap consisted of a square polyethylene bucket of $0.5 \mathrm{~m}^{2}$ and $20 \mathrm{~cm}$ high. They were placed directly on the ground and fixed with wooden stakes. A layer of grease was applied around the edge of each trap to prevent seed predation. Small holes were made in trap sides to avoid rainwater accumulation and subsequent seed decay (Cubina \& Aide, 2001).

The seeds were separated, quantified and taxonomically identified in the laboratory. The botanical identification was made by comparison with reproductive material from herbarium specimens deposited at the Prisco Bezerra Herbarium - EAC, Federal University of Ceará, or by fruits in situ, collected during the field trips, with the help of experts and consultation and specialized literature (Forzza et al., 2014).

The seeds were quantified and identified to species or genus level. The species were arranged by families in APG III (2009) and classified in native and exotic species according to Pyšek et al. (2005) and the List of Species of Brazilian Flora. We included in the analysis only whole seeds, fully formed and with an intact seed coat, according to Foster (1985). Immature fruits were considered aborted and discarded from the count because they are not effective in increasing the size of the population (Stephenson, 1981).

During the taxonomic inventory, we determined the dispersal syndromes for the species sampled: 1) anemochoric-abiotic dispersion, diaspores dispersed by the wind, for example, winged or hairy; 2) zoochoric-biotic dispersion, dispersed by animals, are usually fleshy fruits, such as berries and drupes, or have seeds with fleshy appendage; 3) autochory-abiotic dispersion, barochory (weight/gravity) or ballistic (explosive) dispersion without the adjustments mentioned above (Pijl, 1982). We also determined the life form (tree, shrub, herb and liana) and the successional habitat (early and late) of the species.

We calculated the absolute density of total and monthly seed deposition (seeds $/ \mathrm{m}^{2}$ ) for edge and interior, and the relative density of each species: $D R i=(N i / N t) x$ 100, where: $\mathrm{DRi}=$ relative density of species $\mathrm{i}, \mathrm{Ni}=$ number of individuals sampled of species $\mathrm{i}, \mathrm{Nt}=$ total number of individuals sampled of all species (Mueller-Dombois \& Ellenberg, 1974). We evaluated the diversity of species at the edge and interior of the fragment by the Shannon diversity index (H'), which were compared using the T-Hutcheson test (Zar, 1999) using the software Statistica 7.0.

We tested the data collection for normality using the Shapiro-Wilk test $(\mathrm{p}>0.05)$. Then, we carried out analyses of variance (ANOVAs) to observe statistical differences between seed rain in each month with the significance level of $5 \%$ by Tukey's test. We performed a Spearman correlation test (Zar, 1999) between seed rain and the climatic factors (rainfall, temperature and wind) using the software Statistica 7.0.

We did a principal coordinate analysis (PCA) by the program PCORD 6.0 (McCune $\&$ Mefford, 2011) to verify how the dispersal syndrome, life form and successional habitat were arranged in the gradient edge-interior.

\section{RESULTS}

In the 12-month study on seed rain, 23383 seeds were deposited belonging to 38 families 
and 89 different species, with a density of 1134.48 seeds per $\mathrm{m}^{2}$ (Table 1). The family Fabaceae had the highest richness with 16 species, followed by Rubiaceae with 13 and Asteraceae with seven. On the other hand, for seed number, we found 8947 seeds for Fabaceae (38\%), 3978 for Asteraceae (17\%), 3077 for Euphorbiaceae (13.2\%) and 3001 for Rubiaceae (12.8\%).
We found 13396 seeds belonging to 79 species at the edge and 9987 belonging to 67 species at the interior of the forest. Contrary to the first hypothesis of this work, the interior had less species and its Shannon index was smaller than that for the edge (Table 2), which could be explained by the negative correlation between distance from the edge and seed deposition ( $\mathrm{rs}=-0.41, \mathrm{p}=0.048)$.

TABLE 1

List of species found in the seed rain and the occurrence at the edge-interior gradient in a degraded fragment of tropical semideciduous forest

\begin{tabular}{|c|c|c|c|c|c|}
\hline Family/Species & Edge & Interior & Life form & $\begin{array}{c}\text { Succesional } \\
\text { habitat }\end{array}$ & $\begin{array}{l}\text { Dispersion } \\
\text { syndrome }\end{array}$ \\
\hline \multicolumn{6}{|l|}{ Amaranthaceae } \\
\hline Alternanthera brasiliana (L.) Kuntze & $\mathrm{X}$ & & Herb & Early & Auto \\
\hline \multicolumn{6}{|l|}{ Anacardiaceae } \\
\hline Anacardium occidentale L. & & $\mathrm{X}$ & Tree & Late & Zoo \\
\hline Tapirira guianensis Aubl. & $\mathrm{X}$ & $\mathrm{X}$ & Tree & Early & Zoo \\
\hline \multicolumn{6}{|l|}{ Annonaceae } \\
\hline Xylopia aromatica (Lam.) Mart. & $\mathrm{X}$ & $\mathrm{X}$ & Tree & Early & Zoo \\
\hline \multicolumn{6}{|l|}{ Apocynaceae } \\
\hline Asclepias curassavica L. & $X$ & & Herb & Early & Ane \\
\hline Calotropis procera (Aiton) W. T. Aiton & $\mathrm{X}$ & $\mathrm{X}$ & Shrub & Early & Ane \\
\hline \multicolumn{6}{|l|}{ Arecaceae } \\
\hline Acrocomia intumescens Drude & $\mathrm{X}$ & $\mathrm{X}$ & Tree & Late & Zoo \\
\hline \multicolumn{6}{|l|}{ Asteraceae } \\
\hline Bidens pilosa $\mathrm{L}$. & $X$ & $\mathrm{X}$ & Shrub & Early & Zoo \\
\hline Blainvillea acmella (L.) Philipson & $\mathrm{X}$ & $\mathrm{X}$ & Herb & Early & Ane \\
\hline Centratherum punctatum Cass. & $\mathrm{X}$ & & Herb & Early & Ane \\
\hline Elephantopus elongatus Gardner & $\mathrm{X}$ & & Herb & Early & Ane \\
\hline Elephantopus hirtiflorus DC. & $\mathrm{X}$ & & Herb & Early & Ane \\
\hline Wedelia calycina Rich. & $\mathrm{X}$ & $\mathrm{X}$ & Herb & Early & Ane \\
\hline Tilesia baccata (L.f.) Pruski & $\mathrm{X}$ & $\mathrm{X}$ & Shrub & Early & Ane \\
\hline \multicolumn{6}{|l|}{ Bignoniaceae } \\
\hline Tabebuia aurea (Silva Manso) Benth. \& Hook.f. ex S. Moore & $\mathrm{X}$ & $\mathrm{X}$ & Tree & Late & Ane \\
\hline \multicolumn{6}{|l|}{ Bixaceae } \\
\hline Cochlospermum regium (Mart. ex Schrank) Pilg. & $\mathrm{X}$ & & Shrub & Early & Ane \\
\hline Cochlospermum vitifolium (Willd.) Spreng. & $\mathrm{X}$ & $\mathrm{X}$ & Tree & Late & Auto \\
\hline \multicolumn{6}{|l|}{ Boraginaceae } \\
\hline Cordia oncocalyx Allemão & $\mathrm{X}$ & $\mathrm{X}$ & Tree & Early & Ane \\
\hline \multicolumn{6}{|l|}{ Burseraceae } \\
\hline Protium heptaphyllum (Aubl.) Marchand & $\mathrm{X}$ & $\mathrm{X}$ & Tree & Early & Zoo \\
\hline \multicolumn{6}{|l|}{ Cannabaceae } \\
\hline Trema micrantha (L.) Blume & & $\mathrm{X}$ & Tree & Early & Zoo \\
\hline \multicolumn{6}{|l|}{ Cappareaceae } \\
\hline Cynophalla flexuosa (L.) J. Presl & $\mathrm{X}$ & $\mathrm{X}$ & Tree & Early & Zoo \\
\hline
\end{tabular}


TABLE 1 (Continued)

\begin{tabular}{|c|c|c|c|c|c|}
\hline Family/Species & Edge & Interior & Life form & $\begin{array}{c}\text { Succesional } \\
\text { habitat }\end{array}$ & $\begin{array}{l}\text { Dispersion } \\
\text { syndrome }\end{array}$ \\
\hline \multicolumn{6}{|l|}{ Chrysobalanaceae } \\
\hline Hirtella racemosa Lam. & & $\mathrm{X}$ & Shrub & Late & Zoo \\
\hline \multicolumn{6}{|l|}{ Combretaceae } \\
\hline Buchenavia tetraphylla R. A. Howard & & $\mathrm{X}$ & Tree & Late & Zoo \\
\hline Terminalia catappa $\mathrm{L}$. & $\mathrm{X}$ & & Tree & Early & Zoo \\
\hline \multicolumn{6}{|l|}{ Commelinaceae } \\
\hline Commelina diffusa Burm. f. & $\mathrm{X}$ & & Herb & Early & Zoo \\
\hline Commelina virginica $\mathrm{L}$. & $\mathrm{X}$ & & Herb & Early & Zoo \\
\hline \multicolumn{6}{|l|}{ Convolvulaceae } \\
\hline Evolvulus ovatus Fernald & $\mathrm{X}$ & & Herb & Early & Ane \\
\hline \multicolumn{6}{|l|}{ Cyperaceae } \\
\hline Cyperus cayennensis Willd. ex Link & $\mathrm{X}$ & & Herb & - & Auto \\
\hline Cyperu slaxus Lam. & $\mathrm{X}$ & & Herb & - & Auto \\
\hline \multicolumn{6}{|l|}{ Dilleniaceae } \\
\hline Curatella americana L. & & $\mathrm{X}$ & Tree & Early & Zoo \\
\hline \multicolumn{6}{|l|}{ Euphorbiaceae } \\
\hline Croton blanchetianus Baill. & $\mathrm{X}$ & & Herb & Early & Auto \\
\hline Croton sonderianus Müll.Arg. & $\mathrm{X}$ & $\mathrm{X}$ & Shrub & Early & Auto \\
\hline Dalechampia pernambucensis Baill. & $\mathrm{X}$ & $\mathrm{X}$ & Liana & - & Auto \\
\hline Euphorbia heterophylla L. & $\mathrm{X}$ & & Herb & Early & Auto \\
\hline \multicolumn{6}{|l|}{ Fabaceae } \\
\hline \multicolumn{6}{|l|}{ Caesalpinioideae } \\
\hline Bauhinia ungulata $\mathrm{L}$. & $\mathrm{X}$ & $\mathrm{X}$ & Tree & Early & Auto \\
\hline Chamaecrista calycioides (DC. ex Collad.) Greene & $X$ & & Shrub & - & Auto \\
\hline Chamaecrista rotundifolia (Pers.) Greene & $\mathrm{X}$ & & Shrub & - & Auto \\
\hline Hymenaea courbaril $\mathrm{L}$. & $\mathrm{X}$ & $\mathrm{X}$ & Tree & Late & Zoo \\
\hline Libidibia ferrea (Mart. ex Tul.) L. P. Queiroz & $\mathrm{X}$ & $\mathrm{X}$ & Tree & Early & Auto \\
\hline Senna obtusifolia (L.) H. S. Irwin \& Barneby & $\mathrm{X}$ & $\mathrm{X}$ & Herb & Early & Auto \\
\hline \multicolumn{6}{|l|}{ Mimosoideae } \\
\hline Enterolobium contortisiliquum (Vell.) Morong & $X$ & $\mathrm{X}$ & Tree & Early & Zoo \\
\hline Mimosa hirsutissima Mart. & $\mathrm{X}$ & $\mathrm{X}$ & Shrub & - & Auto \\
\hline Mimosa somnians Humb. \& Bonpl. ex Willd. & $\mathrm{X}$ & $\mathrm{X}$ & Tree & - & Auto \\
\hline Piptadenia stipulacea (Benth.) Ducke & $X$ & $\mathrm{X}$ & Tree & Early & Auto \\
\hline Prosopis juliflora (Sw.) DC. & $\mathrm{X}$ & $\mathrm{X}$ & Tree & Early & Zoo \\
\hline \multicolumn{6}{|l|}{ Papilonioideae } \\
\hline Abrus precatorius $\mathrm{L}$. & $\mathrm{X}$ & $\mathrm{X}$ & Liana & Early & Zoo \\
\hline Calopogon iummucunoides Desv. & $\mathrm{X}$ & $\mathrm{X}$ & Liana & Late & Auto \\
\hline Dioclea grandiflora Mart. ex Benth. & $\mathrm{X}$ & $\mathrm{X}$ & Liana & - & Auto \\
\hline Dioclea sclerocarpa Ducke & $\mathrm{X}$ & $\mathrm{X}$ & Liana & Early & Auto \\
\hline Vatairea macrocarpa (Benth.) Ducke & $\mathrm{X}$ & $\mathrm{X}$ & Tree & Early & Ane \\
\hline \multicolumn{6}{|l|}{ Lamiaceae } \\
\hline Marsypianthes chamaedrys (Vahl) Kuntze & $\mathrm{X}$ & & Herb & - & Auto \\
\hline Vitex flavens Kunth & & $\mathrm{X}$ & Shrub & - & Zoo \\
\hline \multicolumn{6}{|l|}{ Loganiaceae } \\
\hline Spigelia anthelmia L. & & $\mathrm{X}$ & Herb & Early & - \\
\hline Strychnos parvifolia A. DC. & & $\mathrm{X}$ & Liana & Early & Zoo \\
\hline
\end{tabular}


TABLE 1 (Continued)

\begin{tabular}{|c|c|c|c|c|c|}
\hline Family/Species & Edge & Interior & Life form & $\begin{array}{c}\text { Succesional } \\
\text { habitat }\end{array}$ & $\begin{array}{l}\text { Dispersion } \\
\text { syndrome }\end{array}$ \\
\hline \multicolumn{6}{|l|}{ Malvaceae } \\
\hline Guazuma ulmifolia Lam. & $\mathrm{X}$ & $\mathrm{X}$ & Tree & Early & Zoo \\
\hline Pavonia cancellata (L.) Cav. & & $\mathrm{X}$ & Herb & Early & Auto \\
\hline Pseudobombax marginatum (A.St.-Hil.) A. Robyns & $X$ & $\mathrm{X}$ & Tree & Late & Ane \\
\hline Sida jussiaeana DC. & $\mathrm{X}$ & & Herb & - & Auto \\
\hline Sida linifolia Cav. & $\mathrm{X}$ & & Herb & Early & Auto \\
\hline \multicolumn{6}{|l|}{ Melastomataceae } \\
\hline Mouriricearensis Huber & $X$ & $X$ & Shrub & - & Zoo \\
\hline \multicolumn{6}{|l|}{ Moraceae } \\
\hline Brosimum gaudichaudii Trécul & $\mathrm{X}$ & $\mathrm{X}$ & Tree & Early & Zoo \\
\hline \multicolumn{6}{|l|}{ Myrtaceae } \\
\hline Campomanesia sp. & $\mathrm{X}$ & $\mathrm{X}$ & Tree & - & - \\
\hline Psidium guajava $\mathrm{L}$. & $\mathrm{X}$ & $\mathrm{X}$ & Tree & Early & Zoo \\
\hline Psidium sp. & $\mathrm{X}$ & $\mathrm{X}$ & Tree & - & - \\
\hline \multicolumn{6}{|l|}{ Ochnaceae } \\
\hline Ouratea fieldingiana (Gardner) Engl. & $X$ & $X$ & Tree & - & Zoo \\
\hline \multicolumn{6}{|l|}{ Opiliaceae } \\
\hline Agonandra brasiliensis Miers ex Benth. \& Hook. f. & $X$ & $X$ & Tree & Early & Zoo \\
\hline \multicolumn{6}{|l|}{ Poaceae } \\
\hline Dactyloctenium aegyptium (L.) Willd. & $\mathrm{X}$ & & Herb & Early & Auto \\
\hline Panicum trichoides Sw. & $\mathrm{X}$ & $\mathrm{X}$ & Herb & Early & Auto \\
\hline Setaria paucifolia (Morong) Lindm. & $\mathrm{X}$ & $\mathrm{X}$ & Herb & - & Zoo \\
\hline \multicolumn{6}{|l|}{ Polygonaceae } \\
\hline Coccoloba latifolia Lam. & $\mathrm{X}$ & $X$ & Tree & Early & Zoo \\
\hline \multicolumn{6}{|l|}{ Rubiaceae } \\
\hline Borreria latifolia (Aubl.) K. Schum. & $X$ & $\mathrm{X}$ & Herb & Early & Auto \\
\hline $\begin{array}{l}\text { Borreria palustris (Cham. \& Schltdl.) Bacigalupo \& E. L. } \\
\text { Cabral }\end{array}$ & $X$ & $\mathrm{X}$ & Herb & - & Auto \\
\hline Borreria verticillata (L.) G. Mey. & $\mathrm{X}$ & $\mathrm{X}$ & Herb & Early & Auto \\
\hline Diodella apiculata (Willd. ex Roem. \& Schult.) Delprete & $\mathrm{X}$ & & Herb & Early & Auto \\
\hline Diodella teres (Walter) Small & $\mathrm{X}$ & $X$ & Herb & - & Auto \\
\hline Emmeo rhizaumbellata (Spreng.) K. Schum. & $\mathrm{X}$ & $\mathrm{X}$ & Liana & - & Ane \\
\hline Faramea nitida Benth. & $\mathrm{X}$ & $X$ & Shrub & - & Zoo \\
\hline Genipa americana $\mathrm{L}$. & $X$ & $\mathrm{X}$ & Tree & Early & Zoo \\
\hline Guettarda angelica Mart. ex Müll. Arg. & $X$ & $\mathrm{X}$ & Shrub & Early & Zoo \\
\hline Ixora coccinea $\mathrm{L}$. & $X$ & $X$ & Shrub & Early & Zoo \\
\hline Ixora acuminata Müll. Arg. & $\mathrm{X}$ & $\mathrm{X}$ & Shrub & Early & Zoo \\
\hline Randia armata (Sw.) DC. & $\mathrm{X}$ & $\mathrm{X}$ & Tree & Early & Zoo \\
\hline Richardia grandiflora (Cham. \& Schltdl.) Steud. & $\mathrm{X}$ & & Herb & - & Zoo \\
\hline \multicolumn{6}{|l|}{ Sapotaceae } \\
\hline Manilkara triflora (Allemão) Monach. & $X$ & $X$ & Tree & Late & Zoo \\
\hline \multicolumn{6}{|l|}{ Simaroubaceae } \\
\hline Simarouba versicolor A.St.-Hil. & & $X$ & Tree & Late & Zoo \\
\hline \multicolumn{6}{|l|}{ Solanaceae } \\
\hline Solanum paniculatum $\mathrm{L}$. & $X$ & $\mathrm{X}$ & Shrub & Early & Zoo \\
\hline \multicolumn{6}{|l|}{ Turneraceae } \\
\hline Turnera subulata $\mathrm{Sm}$. & $\mathrm{X}$ & $\mathrm{X}$ & Herb & - & Zoo \\
\hline
\end{tabular}


TABLE 1 (Continued)

$\begin{array}{lcccccc}\quad \text { Family/Species } & \text { Edge } & \text { Interior } & \text { Life form } & \begin{array}{c}\text { Succesional } \\ \text { habitat }\end{array} & \begin{array}{c}\text { Dispersion } \\ \text { syndrome }\end{array} \\ \begin{array}{l}\text { Verbenaceae } \\ \text { Lantana camara } \text { L. }\end{array} & \text { X } & \text { X } & \text { Shrub } & \text { Early } & \text { Auto } \\ \text { Urticaceae } \\ \begin{array}{l}\text { Cecropia palmata } \text { Willd. } \\ \hline\end{array}\end{array}$

TABLE 2

Absolute density, species richness and Shannon index (nats/ind.) in the edge, interior forest and full fragment

\begin{tabular}{lccc}
\multirow{2}{*}{ Plant Diversity } & \multicolumn{3}{c}{ Indices } \\
& Absolute density & Richness & Shannon \\
Edge & 13396 & 76 & $1.69 *$ \\
Interior & 9987 & 68 & $1.25^{*}$ \\
Full fragment & 23374 & 88 & $1.97 *$
\end{tabular}

*Values significantly different by T-Hutcheson test $\mathrm{p}<0.05$.

When comparing species at the edge and in the interior, Piptadenia stipulacea (Benth.) Ducke was the most abundant species for both, with 812 and 786 seeds respectively, while Evolvulus ovatus Fernald was the rarest species, presenting only one seed in the interior. Of all edge species, 17 did not appear in the interior, whereas, 10 were not recorded from edge.

We found nine alien species in the seed rain and most of them are more significantly deposited in edge $(\mathrm{F}=15.007, \mathrm{p}<0.01)$, except for Ixora coccinea L. (Table 3). Although appeared in interior, some of these species, like
Calotropis procera (Aiton) W. T. Aiton, Dactyloctenium aegyptium (L.) Willd. and Prosopis juliflora (Sw.) DC., reached a maximum of $60 \mathrm{~m}$ inside the fragment, remaining near the edge region.

The species found in the seed rain presented $64 \%$ (57 species) of similarity with the floristic list of the study area, i.e., plants with autochthonous seeds, which originate from the fragment itself. Meanwhile, $36 \%$ (32 species) of the species had allochthonous origin, native species coming from another fragment or alien species. Most of this allochthonous were found on the forest edge.

The highest deposition rates occurred in October/2009 and the lowest ones in February/2010, with 5901 and 430 diaspores, respectively. The largest range of deposition occurred in the dry season (August/2009 to December/2009), in which $66.8 \%$ of the total seeds obtained in the year were deposited. Moreover, the deposition rates between the seasons were significantly different (Fig. 1; F $=7.1, \mathrm{p}<0.05)$.

TABLE 3

Quantity and exotic classification of alien species found in the edge-interior gradient

\begin{tabular}{lccl}
\multicolumn{1}{c}{ Alien species } & \multicolumn{3}{c}{ Characterization } \\
Bidens pilosa L. & Edge & Interior & \multicolumn{1}{c}{ Classification } \\
Calotropis procera (Aiton) W.T.Aiton & 372 & 198 & Naturalized \\
Commelina virginica L. & 103 & 9 & Invasive \\
Dactyloctenium aegyptium (L.) Willd. & 7 & - & Invasive \\
Ixora acuminata Müll.Arg. & 119 & 4 & Naturalized \\
Ixora coccinea L. & 173 & 77 & Invasive \\
Prosopis juliflora (Sw.) DC. & 151 & 142 & Invasive \\
Terminalia catappa L. & 192 & 10 & Naturalized \\
Tilesia baccata (L.f.) Pruski & 5 & - & Naturalized \\
\hline
\end{tabular}




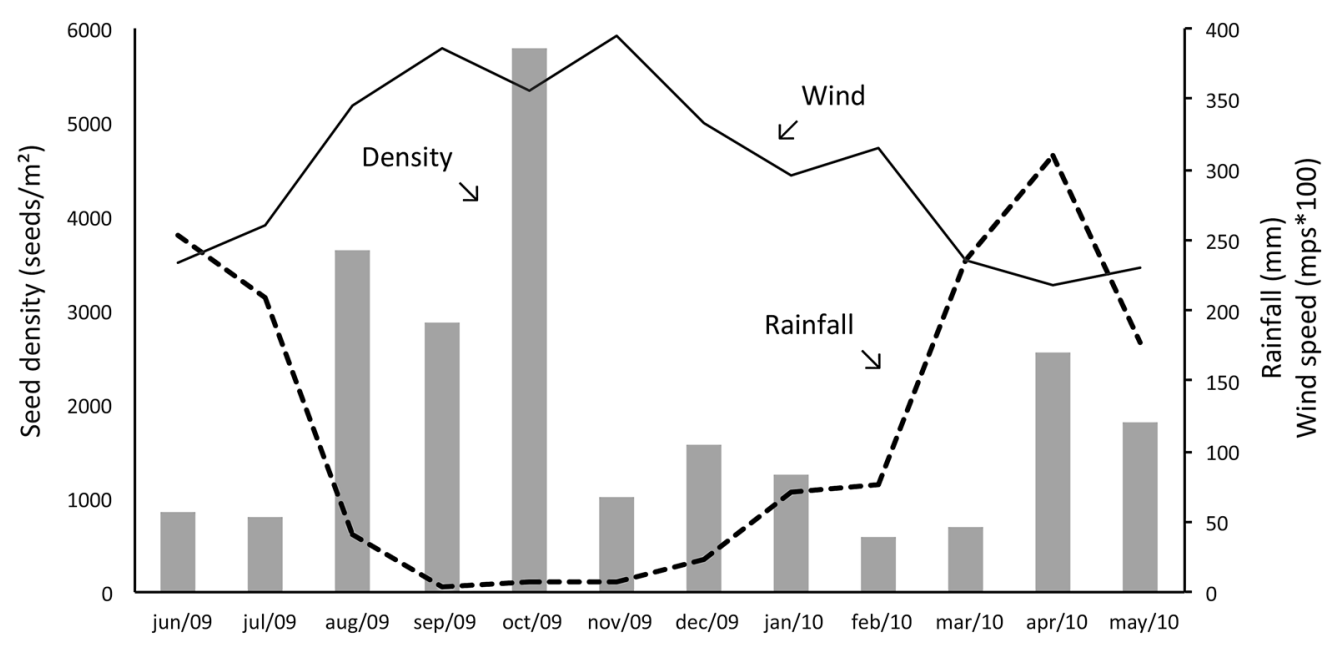

Period of evaluation

Fig. 1. Monthly deposition of seeds $\left(\right.$ seeds $\left./ \mathrm{m}^{2}\right)$, rainfall $(\mathrm{mm})$ and wind speed $(\mathrm{mps} * 100)$ in the study area during the period from June/2009 to May/2010.

The Spearman correlation test between rainfall and seed deposition was significant ( $\mathrm{rs}=-0.2339, \mathrm{p}=0.0443$ ), showing that the number of seeds increases with the decrease of monthly precipitation in the area (Fig. 1). On the other hand, we observed a positive correlation between seed deposition with mean monthly temperature ( $\mathrm{rs}=0.3644, \mathrm{p}=$ 0.0378). Although we did not observe correlation between wind speed and direction (for the east during the all year) with seed deposition ( $\mathrm{p}$ $=0.28$ ), we verified that the major deposition of seeds occurred at the same time of high wind speed (Fig. 1).

We found a similar percentage for biotic (45\%) and abiotic (52\%) dispersal syndromes: $45 \%$ of animal dispersed species, $35 \%$ of autochorous species, $17 \%$ of wind dispersed species and three percenters undetermined (Table 1). There was a largest and significantly proportion of anemochorous and autochorous species fructified during the dry season, while zoochorous diaspores dominated during the rainy season (Fig. 2).

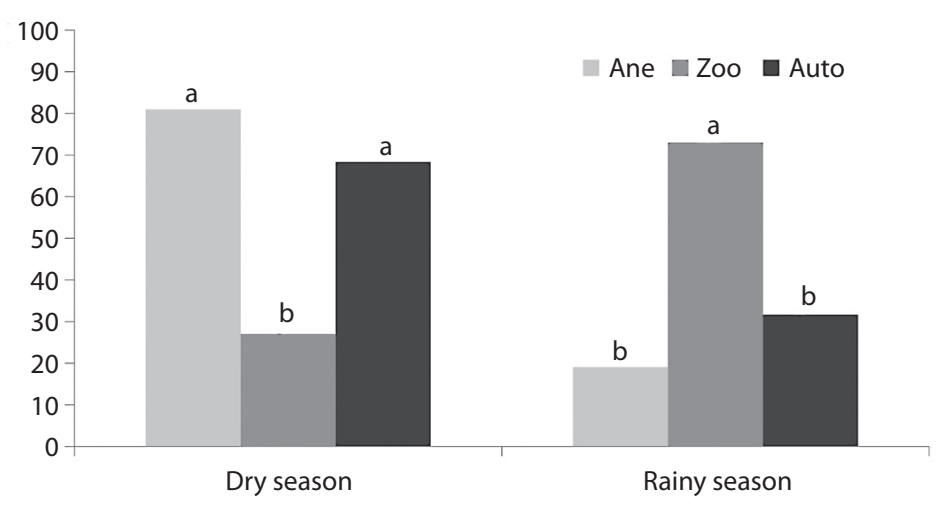

Fig. 2. Deposition of seeds per syndrome and season (\%). Zoo $=$ zoochory, Auto $=$ authochory, Ane $=$ anemochory. The letters $\mathrm{a}$ and $\mathrm{b}$ are statistically different by ANOVA followed by Tukey test $(5 \%)$. 
The zoochorous species were most commonly found in the center of the fragment, while the autochorous and anemochorous were observed more frequently at the edge (Fig. 3). We compared the eigenvalues of the graph with the eigenvalues of randomization analyses and found a significant explanation (Axis $1=$ 0.7841 and Axis $2=0.6207 ; \mathrm{p}<0.05$ ).

We obtained $66 \%$ of woody species (39\% was tree, $19 \%$ shrub and $8 \%$ lianas) and $34 \%$ was herbaceous. Moreover, $63 \%$ was early-successional species, $12 \%$ was latesuccessional and $25 \%$ undetermined (Table 1). From these characters, we found early successional species more in edge areas and late successional in interior (Fig. 4, Axis $1=0.89$ and Axis $2=0.503 ; p<0.05$ ). However, we did not find a distribution pattern for life form (low explanation from Axis; $\mathrm{p}=0.47$ ).

\section{DISCUSSION}

The absolute density of seeds found in the area resembles other studies in semideciduous forests (Araujo, Longhi, Barros, \& Brena, 2004; Marimon \& Felfili, 2006; Lagos \& Marimon, 2012). However, the total density of seed deposition and the number of species in the seed rain are below the values observed for tropical forests (Grombone-Guaratini \& Rodrigues, 2002; Hardesty \& Parker, 2002; Marimon \& Felfili, 2006; Martini \& Santos, 2007). The results for the seed rain can be quite variable, as they reflect the specific differences of each community studied and, consequently, the environmental factors that regulate the forest.

Generally, seed rain for an area indicates the species that are producing fruits in the

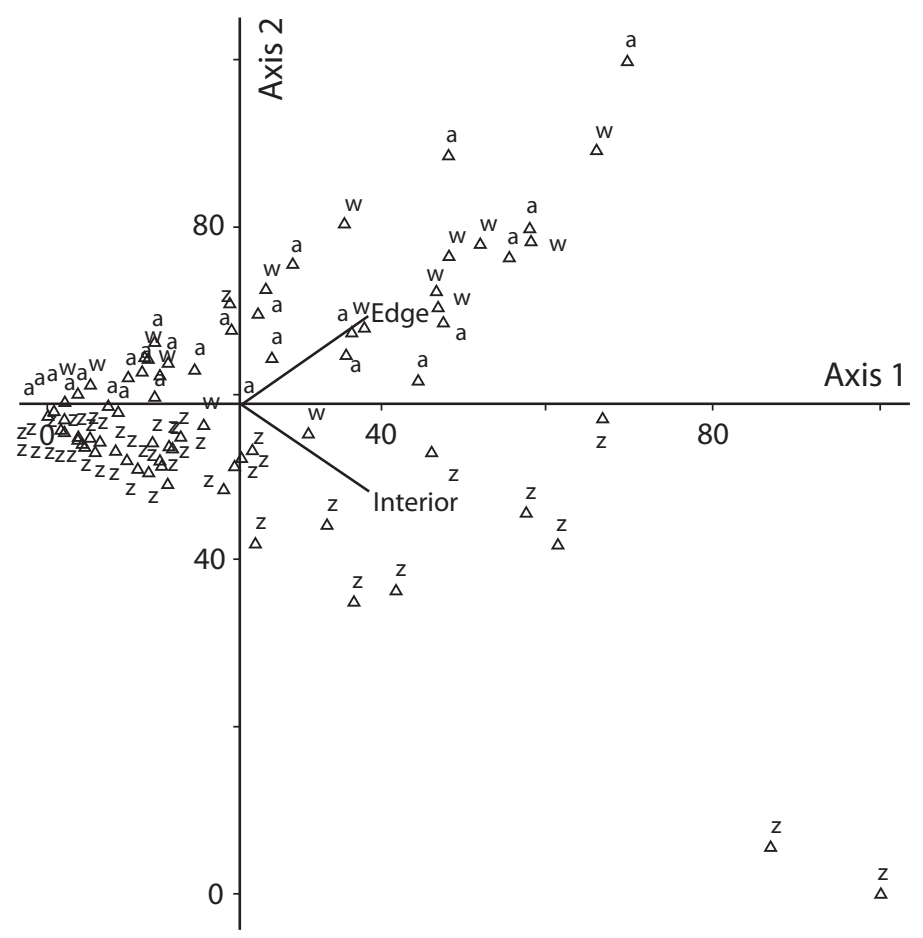

Fig. 3. Principal coordinate analysis for the edge and interior areas by dispersal syndromes. $Z=$ zoochory, $A=$ autochory, $\mathrm{W}=$ wind dispersed or anemochory. 


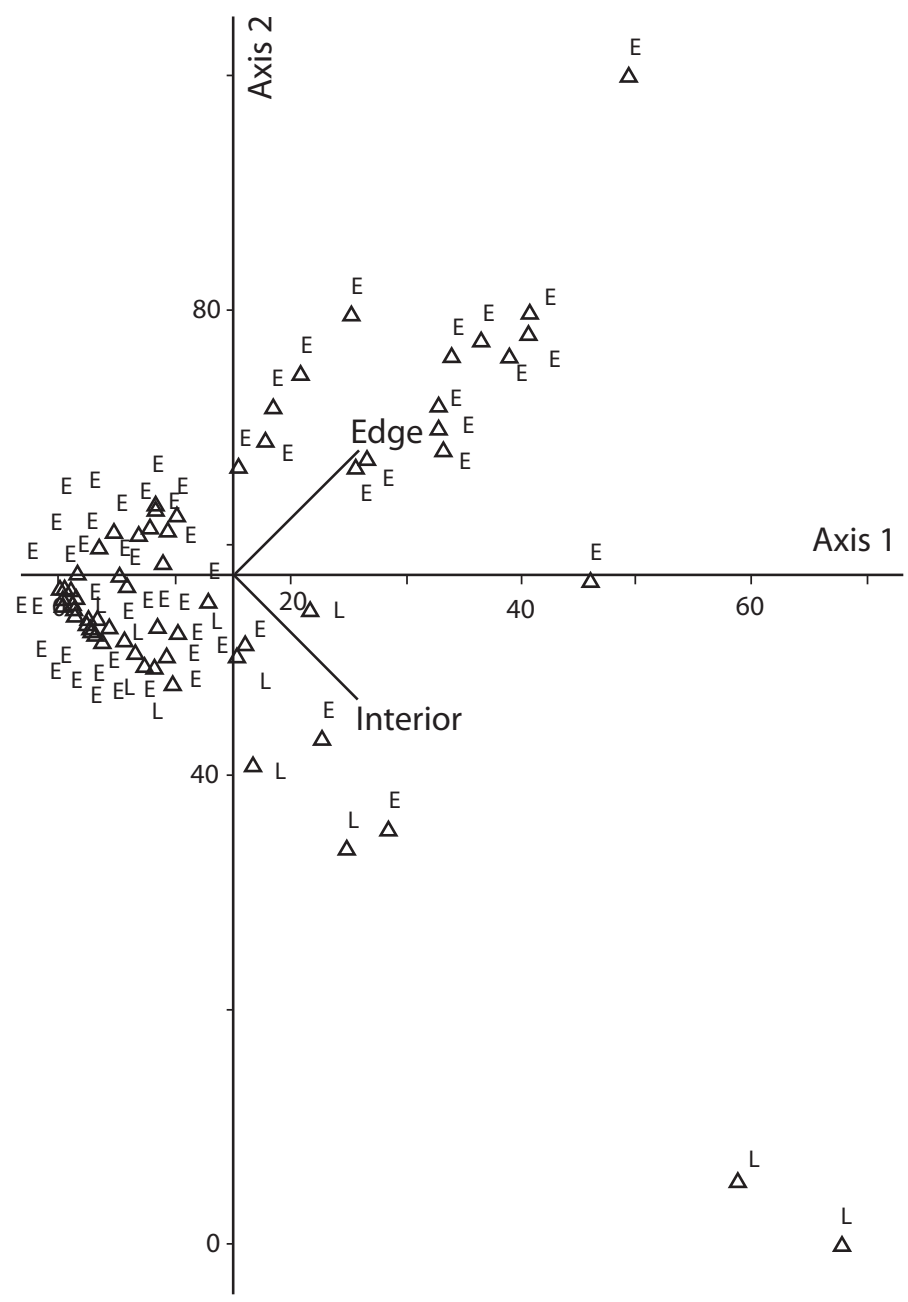

Fig. 4. Principal coordinate analysis for the edge and interior areas by successional habitat. $\mathrm{E}=$ early, $\mathrm{L}=$ late.

immediate neighborhood of the plots and, consequently, on the neighborhood of the collectors (Khurana \& Singh, 2001). The major diversity of seeds in this area is self-generated, since the fragment is located in the urban center and has few floristic connections with other forest fragments (Diogo, Holanda, Oliveira-Filho, \& Bezerra, 2014) and may indicate a high degree of isolation in the landscape. Meanwhile, there are some allochthonous species that may represent the species brought by anthropic influence and species with long-distance dispersion.

The magnitude of the flux of allochthonous seeds across the edge and the dispersal distance into the forest depended on the structure of the vegetation on the edge and on the frugivore community (Fox, Taylor, Fox, \& Williams, 1997; Oosterhoorn \& Kappelle, 2000; Cadenasso \& Pickett, 2001). The edge acts as a direct receiver of seeds from surrounding areas and contains no or few barriers to establishment (Aizen \& Feinsinger, 1994; Murcia, 1995; Schnitzer \& Bongers, 2002; Fahrig, 2003), therefore, also contributes to input of a wide variety of alien species.

Although García and Chinea (2014) found no significant difference between mean number of native versus non-native seeds arriving 
under trees, a study in this same fragment found a greater number of seedlings in the interior (Diogo, Silva, Morais, Melo, \& Voltolini, 2012). The diaspores of species can also reach the interior, but will have to go through many factors to establishment, like different conditions of germination and maturation, survival of seedlings and competition.

The sharp decline in the presence of alien species with distance from the edge is due to dispersal limitations and the dense structure of vegetation that prevented colonization of the forest interior by limiting light and dispersal (Brothers \& Spingarn, 1992; Cadenasso \& Pickett, 2001; Holway, 2005). The physical architecture of the plants on the edge or the permeability of the community to the invasive flux can function as limitations for the dispersal (Cadenasso \& Pickett, 2001). Four species have invasive potential, three (except C. virginica) can be considered invasive in this area since they have the ability to maintain the population and disperse into new areas.

There are five naturalized species which can establish a self-perpetuating population, but they are restricted to areas near the point of introduction, not occupying new areas or reaching long distances in the fragment. The importance of edge effects caused by alien species at natural ecological boundaries generally deserves further examination.

The large amount of seed deposition in the dry season is expected for species in this vegetation formation, this strategy ensures the dominance of these species because the seeds present a better chance of germination and establishment with the onset of rains. Seed dispersal in the dry period may confer advantages to the species by reducing interspecific competition for dispersers and ensuring an early recruitment, besides contributing to a subsequent formation of an extensive seedling bank.

The increase in the input of seeds is a primary response resulting immediately and directly from the effects of edge creation. This amount of seeds in areas near the edge occurs due to vegetation gaps. Opening areas cause higher incidence of sunlight and local temperature increase, which influence positively the deposition and establishment of seeds, mainly early successional species (Lovejoy et al., 1986; Murcia, 1995; Marimon \& Felfili, 2006). The dominance of pioneer species on the seed rain may be explained by the anthropogenic influence, these species are common in areas with early successional stage (Guariguata \& Ostertag, 2001).

The tropical vegetation presents a great abundance of zoochoric species, followed by anemochoric and autochoric (Pijl, 1982; Howe \& Smallwood, 1982). The anemochory and autochory predominates in vegetation types associated with dry climates and open and anthropic areas (Howe \& Smallwood, 1982; Tetetla-Rangel, Hernández-Stefanoni, \& Dupuy, 2013), like the edges and gaps. Animal vectors may visit trees for a number of purposes: feeding, resting, sexual display, or roosting; during any of these activities, fruits or seeds consumed elsewhere may be dropped below the visited trees (García \& Chinea, 2014).

Wind dispersal frequently follows a decay function in which the number of dispersed seeds declines with the distance from the edge (Cadenasso \& Pickett, 2001). Our study demonstrates that a forest edge can act as a direct barrier to wind-dispersed seeds, quantifying the flux of seeds into a forest patch. Therefore, the wind dispersal can be limited by low wind speed, low height of seed release and physical obstruction by the forest vegetation (Cadenasso \& Pickett, 2001; Willson \& Crome, 1989). The dispersal and successional spectrum was dependent on climatic seasonality, spatio-temporal changes in the environmental conditions may affect important ecological processes for dispersal, as we see by the correlation between seed deposition and rainfall and temperature.

This small fragment has conditions to maintain the regenerative control of the vegetal community and can be used as an indicator of reproduction and behavior of the species in a medium- and long-term and the regenerative capacity of this forest by input on edge and interior of the forest. Furthermore, they can act as important sources of seed for restoration of 
degraded areas in the neighborhood or as stepping stones. These patterns demonstrate the importance of conservation and management of small fragments, even if they are isolated in the landscape, to avoid the degradation caused by edge effects.

\section{ACKNOWLEDGMENTS}

We thank the Programa de Educação Tutorial (PET) - Biological Sciences of Federal University of Ceará and its researchers for the help on the field work, as well as for them logistical support. Carlos Lineu Frota Bezerra and Luiz Wilson Lima-Verde for the help on the identification of the seeds.

\section{RESUMEN}

Deposición de semillas en el gradiente borde-interior de un fragmento degradado de bosque semideciduo tropical, Noreste de Brasil. La estructura, dinámica y densidad de poblaciones de plantas en diferentes ecosistemas son controladas por estacionalidad climática. La lluvia de semillas contribuye tanto al establecimiento y mantenimiento de los bosques, así como a la recuperación de áreas alteradas cerca de los fragmentos de bosque. El objetivo de este estudio es evaluar la tasa de deposición de diferentes semillas de especies endémicas y exóticas de árboles tanto al borde y como al interior del bosque. El área de estudio es un fragmento de bosque de 4 hectáreas ubicado en el campus de la Universidad Federal de Ceará. Para medir la lluvia de semillas, 80 recolectores fueron suspendidos a 20 $\mathrm{cm}$ del suelo. Las muestras fueron recolectadas mensualmente durante un año (Junio 2009-Mayo 2010), el material fue analizado en el laboratorio y las diásporas (frutos y semillas) fueron cuantificadas e identificadas taxonómicamente. Encontramos 23383 semillas pertenecientes a 38 familias y 89 especies, con una densidad de 1134.48 semillas $\mathrm{m}^{2}$. Las familias Rubiaceae y Fabaceae fueron las más representativas, con mayor cantidad de semillas. La deposición de la lluvia de semillas fue influenciada por la estacionalidad y, en consecuencia por la temperatura y la precipitación. Existe una clara diferenciación entre el borde y el interior del bosque, una gran cantidad de semillas nativas con dispersión por animales y de dispersión tardía están presentes en el interior del bosque, comparado a un considerable número de semillas pertenecientes a especies no nativas con dispersión abiótica en el borde del bosque. Fragmentos pequeños como este pueden servir como una fuente importante de semillas para las áreas degradadas adyacentes, lo que demuestra la importancia de la conservación y manejo de pequeños fragmentos para evitar la degradación causada por los efectos de borde.

Palabras clave: estacionalidad, especies exóticas, dispersión, sucesión, forma de vida.

\section{REFERENCES}

Aizen, M. A., \& Feinsinger, P. (1994). Forest fragmentation, pollination, and plant reproduction in a Chaco dry forest, Argentina. Ecology, 75, 330-351.

Araujo, M. M., Longhi, J. S., Barros, P. L. C., \& Brena, D. A. (2004). Caracterização da chuva de sementes, banco de sementes do solo e banco de plântulas em Floresta Estacional Decidual ripária Cachoeira do Sul, RS, Brasil. Sciencia Forestalis, 66, 128-141.

Angiosperm Phylogeny Group III. (2009). An update of the Angiosperm Phylogeny Group classification for the orders and families of flowering plants: APG III. Botanical Journal of the Linnean Society, 161, 105-121.

Baider, C., Tabarelli, M., \& Mantovani, W. (1999). O banco de sementes de um trecho de floresta Atlântica Montana (São Paulo, Brasil). Revista Brasileira de Biologia, 59, 319-328.

Brothers, T. S., \& Spingarn, A. (1992). Forest fragmentation and alien plant invasion of central Indiana old-growth forests. Conservation Biology, 6, 91-100.

Burton, J. I., Mladenoff, D. J., Clayton, M. K., \& Forrester, J. A. (2011). The roles of environmental filtering and colonization in the fine-scale spatial patterning of ground-layer plant communities in north temperate deciduous forests. Journal of Ecology, 99, 764-776.

Cadenasso, M. L., \& Pickett, S. T. A. (2001). Effect of edge structure on the flux of species into forest interiors. Conservation Biology, 15, 91-97.

Cubina, A., \& Aide, T. M. (2001). The effect of distance from forest edge on seed rain and soil seed bank in a tropical pasture. Biotropica, 33, 260-267.

Diogo, I. J. S., Silva, R. B., Morais, E. B., Melo, I. R. S., \& Voltolini, J. C. (2012). Edge effects on the vegetation structure in a fragment of semi-deciduous forest, Northeastern Brazil. Revista Biociências, 18(2), 53-60.

Diogo, I. J. S., Holanda, A. E. R., Oliveira-Filho, A. L., \& Bezerra, C. L. F. (2014). Floristic composition and structure of na urban forest remnant of Fortaleza, Ceará. Gaia Scientia (UFPB), 8(1), 266-278.

Du, X., Guo, Q., Gao, X., \& Ma, K. (2007). Seed rain, soil seed bank, seed loss and regeneration of Castanopsis fargesii (Fagaceae) in a subtropical evergreen broadleaved forest. Forest Ecology and Management, 238, 212-219. 
Fahrig, L. (2003). Effects of habitat fragmentation on biodiversity. Annual Review of Ecology, Evolution, and Systematics, 34, 487-515.

Forman, R. T. T., \& Moore, P. N. (1992). Theoretical foundations for understanding boundaries. In A. J. Hansen \& F. Di Castri (Eds.), Consequences for biotic diversity an ecological flows (pp. 327-345). New York: Springer-Verlag.

Forman, R. T. T. (1995). Land mosaics: the ecology of landscape and regions. Cambridge: Cambridge University Press.

Forzza, R. C., Leitman, P., Walter, B. M. T., Costa, A., Pirani, J. R., Morim, M. P., \& Hopkins, M. (2014). Lista de Espécies da Flora do Brasil. Jardim Botânico do Rio de Janeiro. Retrieved from http://floradobrasil. jbrj.gov.br/2010/

Foster, S. A. (1985). Size-dependent territory defense by a damselfish. Oecologia, 67, 499-505.

Fox, B. J., Taylor, J. E., Fox, M. D., \& Williams, C. (1997). Vegetation changes across edges of rainforest remnants. Biological Conservation, 82, 1-13.

García, A. A., \& Chinea, D. (2014). Seed rain under native and non-native tree species in the Cabo Rojo National Wildlife Refuge. Revista de Biología Tropical, 62(3), 1129-1136.

Gosz, J. R. (1991). Fundamental ecological characteristics of landscape boundaries. In M. M. Holland, P. G. Risser, \& R. J. Naiman (Eds.), Ecotones: the role of landscape boundaries in the management and restoration of changing environments (pp. 57-66). New York: Chapman and Hall.

Guariguata, M. R., \& Ostertag, R. (2001). Neotropical secondary forest succession: changes in structural and functional characteristics. Forest Ecology and Management, 148, 185-206.

Grombone-Guaratini, M. T., \& Rodrigues, R. R. (2002). Seed bank and seed rain in a seasonal semi-decidous forest in south-eastern Brazil. Journal of Tropical Ecology, 18, 137-148.

Hardesty, B. D., \& Parker, V. T. (2002). Community seed rain patterns and a comparison to adult community structure in a West African tropical forest. Plant Ecology, 164, 49-64.

Harper, J. L. (1977). Population biology of plants. London: Academic Press.

Harper, K. A., MacDonald, S. E., Burton, P. J., Chen, J., Brosofske, K. D., Saunders, S. D., Euskirchen, E. S., Roberts, D., Jaiteh, M. S., \& Esseen, P. A. (2005). Edge influence on forest structure and composition in fragmented landscapes. Conservation Biology, 19, 768-782.
Harris, L. D. (1988). The fragmented forest: island biogeography theory and the preservation of biotic diversity. Chicago: University of Chicago Press.

Holway, D. A. (2005). Edge effects of an invasive species across a natural ecological boundary. Biological Conservation, 121, 561-567.

Hopkins, M. S., \& Graham, A. W. (1983). The composition of soil seed banks beneath low land tropical rainforest in North Queensland Australia. Biotropica, 15, 90-99.

Howe, H. F., \& Smallwood, J. (1982). Ecology of seed dispersal. Annual Review of Ecology and Systematics, 13, 201-228.

Khurana, E., \& Singh, J. S. (2001). Ecology of seed and seedling growth for conservation and restoration of tropical dry forest: a review. Environmental Conservation, 28, 39-52.

Lagos, M. C. C., \& Marimon, B. S. (2012). Chuva de sementes em uma floresta de galeria no Parque do Bacaba, em Nova Xavantina, Mato Grosso, Brasil. Revista Árvore, 36, 311-320.

Leopold, A. (1933). Game management. Madison: The University of Wisconsin Press.

Lovejoy, T. E., Bierregaard, R. O., Rylands, A. B., Malcolm, J. R., Quintela, C. E., Harper, L. H., Brown, K. S., Powell, A. H., Powell, G. V. N., Schubart, H. O. R., \& Hays, M. B. (1986). Edge and other effects of isolation on Amazon forest fragments. In M. E. Soulé (Ed.), Conservation biology: the science of scarcity and diversity (pp. 257-2851). Sunderland, Massachusetts: Sinauer Associates.

Lovett, G. M., Canham, C. D., Arthur, M. A., Weathers, K. C., \& Fitzhugh, R. D. (2006). Forest ecosystem responses to exotic pests and pathogens in Eastern North America. Bioscience, 56, 395-405.

Marimon, B. S., \& Felfili, J. M. (2006). Chuva de sementes em uma floresta monodominante de Brosimum rubescens Taub. e em uma floresta mista adjacente no Vale do Araguaia, MT, Brasil. Acta Botânica Brasílica, $20,423-432$.

Martini, A. M. Z., \& Santos, F. A. M. (2007). Effects of distinct types of disturbance on seed rain in the Atlantic forest on NE Brazil. Plant Ecology, 190, 81-95.

McCune, B., \& Mefford, M. J. (2011). PC-ORD. Multivariate analysis of ecological data. Version $6 . \mathrm{MjM}$ Software, Glenedan Beach, Oregon.

Mueller-Dombois, D., \& Ellenberg, H. (1974). Aims and methods of vegetation ecology. New York: Wiley.

Murcia, C. (1995). Edges effects in fragmented forest: Implications for conservation. Tree, 10(2), 58-62.

Oosterhoorn, M., \& Kappelle, M. (2000).Vegetation structure and composition along an interior-edge-exterior 
gradient in a Costa Rican montane cloud forest. Forest Ecology and Management, 126, 291-307.

Pakeman, R. J., \& Small, J. L. (2005).The role of the seed bank, seed rain and the timing of disturbance in gap regeneration. Journal of Vegetation Science, 16, 121-130.

Peel, M. C., Finlayson, B. L., \& Mcmahon, T. A. (2007). Updated world map of the Koppen-Geiger climate classification. Hydrology and Earth System Sciences, 11, 1633-1644.

Pickett, S. T. A., \& Cadenasso, M. L. (1995). Landscape ecology: spatial heterogeneity in ecological systems. Science, 269, 331-334.

Pijl, L. V. (1982). Principles of dispersal in higher plants. Berlin: Springer-Verlag.

Pivello, V. R., Petenon, D., Jesus, F. M., Meirelles, S. T., Vidal, M. M., Alonso, R. A. S., Franco, G. A. D. C., \& Metzger, J. P. (2006). Chuva de sementes em fragmentos de floresta Atlântica (São Paulo, SP), sob diferentes situações de conectividade, estrutura florestal e proximidade à borda. Acta Botânica Brasílica, 20, 845-859.

Pyšek, P., Richardson, D. M., Rejmánek, M., Webster, G. L., Williamson, M., \& Kirschner, J. (2005). Alien plants in checklists and floras: towards better communication between taxonomists and ecologists. Taxon, 53, 131-143.

Ramos, C., Buitrago, S. P., Pulido, K. L., \& Vanegas, L. J. (2013). Variabilidad ambiental y respuestas fisiológicas de Polylepis cuadrijuga (Rosaceae) en un ambiente fragmentado en el Páramo de la Rusia (Colombia). Revista Biología Tropical, 61(1), 351-361.

Rodríguez-Pérez, J., Wiegand, K., \& Ward, D. (2011). Interaction between ungulates and bruchid beetles and its effect on Acacia trees: modeling the costs and benefits of seed dispersal to plant demography. Oecology, 167, 97-105.
Schnitzer, S. A., \& Borgers, F. (2002). The ecology of lianas and their role in forests. Trends Ecology and Evolution, 17, 223-230.

Stephenson, A. G. (1981). Flower and fruit abortion: Proximate causes and ultimate functions. Annual Review of Ecology and Systematics, 12, 253-279.

Swaine, M. D., \& Whitmore, T. C. (1988). On the definition of ecological species groups in tropical rain forests. Vegetatio, 75, 81-86.

Tetetla-Rangel, E., Hernández-Stefanoni, J. L., \& Dupuy, J. M. (2013). Patterns of rare woody species richness: the influence of environment, landscape attributes and spatial structure across different special scales. Biodiversity and Conservation, 22, 1435-1450.

Young, K. R., Ewel, J. J., \& Brown, B. J. (1987). Seed dynamic during forest succession in Costa Rica. Vegetatio, 71, 157-173.

Vitousek, P. M., D’Antonio, C. M., Loope, L. D., Rejmánek, M., \& Westbrooks, R. (1997). Introduced species: a significant component of human-caused global change. New Zealand Journal of Ecology, 46, 517-520.

Wiens, J. A. (1992). Ecological flows across landscape boundaries: a conceptual overview. In A. J. Hansen \& F. Di Castri (Eds.), Landscape boundaries: consequences for biotic diversity and ecological flows (217-235). New York: Springer-Verlag.

Wiens, J. A., Stenseth, N. C., Van Horn, B., \& Ims, R. A. (1993). Ecological mechanisms and landscape ecosystems. Oikos, 45, 421-427.

Willson, M. F., \& Crome, F. H. J. (1989). Patterns of seed rain at the edge of a tropical Queensland rain forest. Journal of Tropical Ecology, 5, 301-308.

Zar, J. H. (1999). Biostatistical analysis (4 ${ }^{\text {th }}$ ed.). New Jersey: Prentice Hall. 